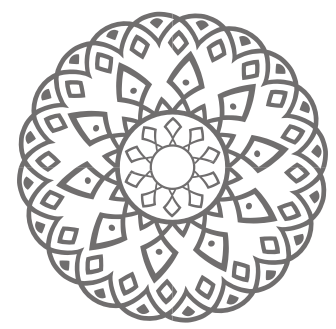

\title{
Legal Aid Post Services at the Indonesian Religious Courts DURING THE COVID-ig PANDEMIC
}

\author{
Ramdani Wahyu Sururie \& Yoghi Arief Susanto
}

\begin{abstract}
Abstrak: Penyebaran COVID-19 telah ditetapkan sebagai darurat kesehatan dan ekonomi yang berdampak pada kehidupan sosial, termasuk pelayanan posko bantuan hukum di Pengadilan Agama. Penelitian ini bertujuan untuk menganalisis jenis, bentuk, dan metode pelayanan Pos Bantuan Hukum di Peradilan Agama serta tingkat akses masyarakat terhadap Peradilan Agama selama periode COVID-19. Penelitian ini menggunakan metode yuridis empiris dengan pendekatan kualitatif. Analisis deskriptif dan eksploratif dilakukan untuk mengidentifikasi layanan Pos Bantuan Hukum di Pengadilan Agama dalam memberikan akses peradilan kepada publik. Penelitian ini juga menggunakan purposive sampling sebelum melakukan wawancara mendalam dengan beberapa informan, termasuk pegawai pengadilan agama, advokat, dan petugas Pos Bantuan Hukum. Hasil penelitian menunjukkan bahwa pelayanan pencatatan perkara di Pos Bantuan Hukum Pengadilan Agama telah dilakukan dalam berbagai bentuk yaitu secara online melalui aplikasi E-Court dan secara manual dengan mengunjungi Pengadilan Agama. Terkait tingkat akses, masyarakat yang mengakses Pengadilan Agama saat pandemi COVID-19 mengalami penurunan. Dengan demikian, penelitian ini menunjukkan bahwa pelayanan Pos Bantuan Hukum di Pengadilan Agama selama periode COVID-19 telah dilakukan secara berbeda di berbagai Pengadilan Agama.
\end{abstract}

Kata kunci: COVID-19; E-Court; Posko Bantuan Hukum; Pengadilan Agama 
Abstract: The spread of the Corona Virus Disease 2019 (COVID-19) has been declared as a health and economic emergency that has an impact on social life, including Legal Aid Post services at the Indonesian Religious Courts. This study aims to analyze the types, forms, and methods of Legal Aid Post services at the Religious Courts and the level of public access to the Religious Courts during the COVID-19 pandemic. This research uses an empirical juridical method with a qualitative approach. Descriptive and exploratory analysis are carried out to identify Legal Aid Post services at the Religious Courts in providing judicial access to the public. This study also uses purposive sampling before conducting in-depth interviews with several informants. These include Religious Court employees, advocates, and Legal Aid Post officers. The results show that the case registration services at the Legal Aid Post for the Religious Courts have been carried out in various forms, namely online through the E-Court application and manually by visiting the Religious Court. Thus, this study shows that Legal Aid Post services at the Indonesian Religious Courts during the COVID-19 pandemic have been carried out differently in various Religious Courts.

Keywords: COVID-19; E-court; Legal Aid Post; Religious Courts 


\section{Introduction}

The spread of the Corona Virus Disease 2019 (COVID-19) has been declared as a health and economic emergency that has an impact on social life, including access to the courts. The condition of the COVID-19 pandemic requires an extensive restriction for people to interact with each other. Offices, including the Religious Courts should meet the standards for handling and preventing COVID-19 that have been set by the government. In turn, this also affects the case process, which requires direct meetings in a court (Anwar, 2020). Anticipating the spread of COVID-19, the Supreme Court of Indonesia issued Circular Letter Number 1 to Number 3 of 2020 concerning Guidelines for Implementation of Tasks during the Prevention Period of the Spread of COVID-19 in the Supreme Court and its Judicial Bodies. One of the items in the Supreme Court Circular is regulating its personnel to work at home. As a result, the legal services to the public faces obstacles. Such services include the services provided by a Legal Aid Post.

According to the Supreme Court Regulation Number 1 of 2014 Article 1 Paragraph 6, Legal Aid Post is defined as a service that is established by and existed at every court of the first level to provide legal services in the form of information, consultation, and legal advice as well as the preparation of legal documents required under the laws and regulations that regulates the power of the judiciary, general courts, religious courts, and state administrative courts. The types of Legal Aid Post services include services in providing information, consultation, legal advice, and making legal documents needed by parties in the Religious Courts, such as making lawsuits/ petition (Article 25 of Supreme Court Regulation No.1 of 2014). Since the COVID-19 pandemic, Legal Aid Post services in the Religious Courts have experienced disruption, especially since large-scale social restrictions imposed.

This research focuses on the restrictions and changes of services in legal aid posts provided by the Religious Courts during the COVID-19 pandemic, especially during the large-scale social restrictions period. Studies on COVID-19 linked to the court services are still relatively scarce. However, there are quite a lot of studies related to COVID-19 and the legal world in general. One of the 
studies related to court services during the pandemic is by RR. Dewi Anggraeni (2020) about "The COVID-19 Pandemic Outbreak Urgency for Electronic Trial Implementation”. RR. Dewi Anggraeni described that trial services through electronic trials helped justice seekers (defendants), if the trial was postponed. However, this would result in losses for the defendants (2020: 7). Imas Novita Juaningsih's research in 2020 about "The Application of Criminal Sanctions for Mask Hoarders in Indonesia During the COVID-19 Pandemic Period" is one of the academic writings related the impact of the COVID-19 on the emergence of mask hoarders. According to the study, to anticipate the hoarding of masks, it is necessary for the government to produce preventive and repressive steps so that the perpetrators of hoarding are deterred (2020: 80).

In normal times, the Legal Aid Post service follows the working hours of the Religious Court, with eight-hours daily services. However, along with the Large-Scale Social Restrictions (PSBB) policy as regulated in Government Regulation Number 21 of 2020 concerning Large-Scale Social Restrictions in the Context of Accelerating Handling of Corona Virus Disease 2019 (COVID-19), there have been restrictions and changes in the services so that public access to the court was changed. This COVID-19 pandemic has posed serious challenges for judicial administrators, including in Indonesia, especially in countries that have imposed lockdowns to overcome the spread of COVID-19 (Jose Igreja Matos, 2020). Although the Large-Scale Social Restrictions to suppress the spread of covid-19 has been enacted, the Religious Courts still provide access to the courts for the justice-seeking society with some restrictions and changes in the service hours. Thus, this study analyzes changes in the types, forms, and methods of Legal Aid Post services that are provided during the COVID-19 pandemic period and the level of public access to the Religious Courts.

The Indonesian government has implemented Large-Scale Social Restrictions. However, people who seek for justice and fight for their rights must be served. To trace data regarding restrictions and changes to post-vacuum services and the level of access to the Religious Courts, an empirical study is conducted with qualitative data collected through interviews and library research. 


\section{Discussion}

\section{Legal Aid Post Services in Religious Courts}

In facing COVID-19 pandemic, especially during the Large-Scale Social Restrictions era, the Religious Courts have provided services to deliver easy access to the public in obtaining justice, including services at Legal Aid Posts. During an interview with ZH from the Soreang Religious Court, he explained that:

"The number of case registrations, without being accompanied by an advocate as a legal attorney, is limited to 15 registrants and served from 08.00 - 12.00. Initially, before the implementation of Large-Scale Social Restrictions, the crowds of parties registering cases could not be avoided, even though the appeal for physical distancing was conveyed through an announcement. However, after the implementation of the Large-Scale Social Restrictions, the Soreang Religious Court enforced strict health protocols, such as providing hand sanitizers, ID cards for registrants, and maintaining physical distance" (ZH. Personal Interview. May 30, 2020).

Legal Aid Post services at the Bandung Religious Court are carried out online during the COVID-19 pandemic following the Supreme Court Regulation No.1 of 2019 concerning the Administration of Cases and Trials in Courts Electronically. For those who are litigating without being accompanied by an advocate, the legal process is conducted online through the provided E-Court corner. To reduce the mobility of the litigants, the Bandung Religious Court has provided a contact number via a website created by a Legal Aid Post officer to serve the making of a lawsuit/ petition. The parties can access the service through http://pabandung.go.id/layanan-hukum/posbakum/posbakum-online. According to AS, who is a chairman of the Bandung Religious Court, the integration of case registration services for parties without lawyers is carried out in the context of court innovation. They are also required to maintain physical distancing during the COVID-19 pandemic (AS Personal Interview, 4 May 2020).

Services provided by the Legal Aid Post of Ngamprah Religious Court refer to the Declaration of the Head of the Ngamprah Religious Court Number W10-A26 / 0761 / HM.02 / III / 2020. According to the edict, case registration services at the Ngamprah Religious Court are carried out online during the COVID-19 pandemic through E-Filling for those who are represented by a lawyer. For parties who 
do not use the services of an advocate, case registration is served manually by visiting the registration corner. According to $\mathrm{SH}$, a Legal Aid Post officer at the Ngamprah Religious Court:

"Letters of the lawsuit are made by officers of the Legal Aid Post online using the Work from Home (WFH) method before the case is registered".

(SH. Personal Interview. April 30, 2020).

At the Karawang Religious Court, case registration services during the COVID-19 pandemic have been carried out from 09.00-12.00. The interview with DM from the Karawang Religious Court reveals that the case registration is still conducted manually; that is, the parties come to the religious court to register the case. According to DM "independent registration through the e-filling application has not been widely understood by the parties so that the local Religious Court still applies manual services." (DM. Personal Interview. 1 May 2020). Meanwhile, for parties who use the services of an advocate, the registration is carried out by lawyers online through an E-Filling application to prevent the people mobilization during the COVID-19 pandemic.

Case registration services at the Depok Religious Court are implemented through an E-Filling application for parties who are assisted by lawyers. Meanwhile, for those who do not use the services of a legal attorney, the service has been postponed (no service), at least from 26 March to 13 May 2020", said AAS who is and advocate assigned to the Depok Religious Court. (AAS. Personal Interview. 1 May 2020).

Meanwhile, the same information was disclosed by DZ, as the Clerk of the Subang Religious Court, he maintained that:

"The Subang Religious Court provides case registration services from 09.00 - 12.00 during the COVID-19 pandemic through the E-Court I E-Filling application for parties who use the services of an advocate, while those who do not use the services of a lawyer, register their cases manually via the registration corner after the parties provide a lawsuit obtained from Legal Aid Post". (DZ. Personal Interview. May 1, 2020).

At the Sumedang Religious Court, case registration services for those who use the services of a lawyer use the E-Filling application. However, the information obtained from HA, the Advocate at the 
Sumedang Religious Court, is that:

"For those who are litigating without a legal representative during the COVID-19 period, the legal process is postponed until an undetermined time" (HA. Personal Interview. April 30, 2020).

During March 2020, the Cimahi Religious Court served registration as usual by imposing health protocols for litigants. Meanwhile, registration admission is closed from 24 April - 09 May 2020. Case registration with the E-Filling application in the e-court application during that period was available for parties using the services of a legal attorney. During the closing period of registration, legal aid post officers actively worked at the Cimahi Religious Court but only served consultations and did not serve for make lawsuit/ petition letters. (RWT. Personal Interview. April 30, 2020).

The interviews with the informants from several Religious Courts reveal that there were variation in the services provided by those Religious Courts during the COVID -19 pandemic, especially during the Large-Scale Social Restrictions period. Table 1 below describes the pattern of postal services at each religious court.

Table 1: Legal Aid Post Services at the Religious Courts during the COVID-19 Era

\begin{tabular}{|lll|}
\hline No $\quad$ Court Name & \multicolumn{1}{c|}{ Form of Service } \\
\hline 1 Bandung Religious Court & 1. $\begin{array}{l}\text { Legal Aid Post officers provide services online } \\
\text { through an application integrated with the } \\
\text { Bandung Religious Court website, namely } \\
\text { http://pabandung.go.id/layananhukum/ } \\
\text { posbakum/posbakum-online. Registrants with }\end{array}$ \\
& $\begin{array}{l}\text { a Statement of Incapability is to be served } \\
\text { manually; }\end{array}$ \\
2. $\begin{array}{l}\text { The complete document is filled into the } \\
\text { E-Court application by the officer. } \\
\text { 3. }\end{array}$ & $\begin{array}{l}\text { Case registration is carried out online via } \\
\text { E-Court for parties who use advocates; } \\
\text { 4. }\end{array}$ \\
& $\begin{array}{l}\text { Registrants without a legal attorney register at } \\
\text { the registration corner after receiving a lawsuit/ } \\
\text { petition from Legal Aid Post; }\end{array}$ \\
\hline
\end{tabular}




\begin{tabular}{|c|c|c|}
\hline No & Court Name & Form of Service \\
\hline 2 & Soreang Religious Court & $\begin{array}{l}\text { 1. Legal Aid Post provides services manually } \\
\text { from } 08.00-12.00 \text {; } \\
\text { 2. The complete document is filled into the } \\
\text { E-Court application by the officer. } \\
\text { 3. Case registration is carried out online via } \\
\text { E-Court for parties who use advocates; } \\
\text { 4. Registrants without a legal attorney register } \\
\text { at the registration corner after receiving a } \\
\text { lawsuit/ petition from Legal Aid Post; }\end{array}$ \\
\hline 3 & $\begin{array}{l}\text { Ngamprah Religious } \\
\text { Court }\end{array}$ & $\begin{array}{l}\text { 1. Legal aid posts provide online services via } \\
\text { telephone and WhatsApp; } \\
\text { 2. The complete document is filled into the } \\
\text { E-Court application by the officer. } \\
\text { 3. Case registration is carried out online via } \\
\text { E-Court for parties who use advocates; } \\
\text { 4. Registrants without a legal attorney register } \\
\text { at the registration corner after receiving a } \\
\text { lawsuit/ petition from the legal aid post; }\end{array}$ \\
\hline 4 & $\begin{array}{l}\text { Karawang Religious } \\
\text { Court }\end{array}$ & $\begin{array}{l}\text { 1. Legal Aid Post provides services manually } \\
\text { from } 09.00-12.00 \text {. } \\
\text { 2. Case registration is carried out online via } \\
\text { E-Court for parties who use advocates; } \\
\text { 3. Registrants without a legal representative } \\
\text { register at the registration corner after } \\
\text { receiving a lawsuit/ petition from the legal } \\
\text { aid post. }\end{array}$ \\
\hline 5 & Depok Religious Court & $\begin{array}{l}\text { 1. Case registration is carried out online via } \\
\text { E-Court for parties who use advocates; } \\
\text { 2. Case registrations carried out without the } \\
\text { services of a lawyer are postponed from } \\
\text { March } 26 \text { to May 13, } 2020 \text {. }\end{array}$ \\
\hline 6 & Subang Religious Court & $\begin{array}{l}\text { 1. The legal aid post provides manual lawsuits/ } \\
\text { petition and consultation services from } \\
09.00-12.00 \text {. } \\
\text { 2. Case registration is carried out online via } \\
\text { E-Court for parties who use advocates; } \\
\text { 3. Registrants without a legal attorney register } \\
\text { at the registration corner after receiving a } \\
\text { lawsuit/ petition from the legal aid post. }\end{array}$ \\
\hline 7 & $\begin{array}{l}\text { Sumedang Religious } \\
\text { Court }\end{array}$ & $\begin{array}{l}\text { 1. Case registration is carried out online via } \\
\text { E-Court for parties who use advocates; } \\
\text { 2. Case registrations that are carried out without } \\
\text { the services of an advocate are postponed } \\
\text { indefinitely. }\end{array}$ \\
\hline
\end{tabular}




\begin{tabular}{|ll|}
\hline No $\quad$ Court Name & \multicolumn{1}{c|}{ Form of Service } \\
\hline $8 \quad$ Cimahi Religious Court & 1. $\begin{array}{l}\text { The Legal Aid Post only serves consultations } \\
\text { during the Cimahi Religious Court closes the } \\
\text { registration service. }\end{array}$ \\
2. & Case registration is carried out online via \\
& E-Court for parties using an advocate or without \\
& a lawyer; \\
3. & Case registration is closed from 24 April - 09 \\
& May 2020; \\
4. $\begin{array}{l}\text { During the closing period of registration, the } \\
\text { Cimahi Religious Court accepted registration } \\
\text { for parties using the service of a legal } \\
\text { attorney. }\end{array}$ \\
\hline
\end{tabular}

Source: Interviews with informants

Based on table 1 above, especially during the Large-Scale Social Restrictions period of the COVID-19 pandemic, the access to Religious Courts and the access to obtain Legal Aid Post services in the Religious Courts was carried out with various forms of services. Access to justice for Religious Courts during the COVID-19 pandemic, especially during the Large-Scale Social Restrictions period was different from the times before the COVID-19 pandemic. Table 2 below presents the differences of the Legal Aid Post services between before and during the COVID-19 pandemic.

Table 2: The Different Services in Legal Aid Post before and during the COVID-19 Pandemic in the Religious Courts

\begin{tabular}{|clll|}
\hline No & \multicolumn{1}{c}{$\begin{array}{c}\text { Services Before } \\
\text { COVID-19 }\end{array}$} & \multicolumn{1}{c|}{$\begin{array}{c}\text { Services During } \\
\text { COVID-19 }\end{array}$} & \multicolumn{1}{c|}{ Location } \\
\hline 1 & $\begin{array}{l}\text { Legal Aid Post service } \\
\text { time is carried out } \\
\text { during working hours } \\
\text { from 08.00-16.30 }\end{array}$ & $\begin{array}{l}\text { Legal Aid Post service } \\
\text { time is limited from } \\
09.00-12.00\end{array}$ & $\begin{array}{l}\text { Legal Aid Posts in the } \\
\text { Soreang, Karawang, } \\
\text { and Subang Religious } \\
\text { Courts }\end{array}$ \\
\hline 2 & $\begin{array}{l}\text { Lawsuit/ petition } \\
\text { making and } \\
\text { consultation are carried } \\
\text { out face to face during } \\
\text { the working hours }\end{array}$ & $\begin{array}{l}\text { The use of a lawsuit/ } \\
\text { petition making and } \\
\text { consultation application } \\
\text { is integrated with the } \\
\text { Religious Courts websites } \\
\text { or via telephone and }\end{array}$ & $\begin{array}{l}\text { Legal Aid Post in } \\
\text { the Bandung and } \\
\text { Ngamprah Religious } \\
\text { Courts }\end{array}$ \\
\hline
\end{tabular}




\begin{tabular}{|c|c|c|c|}
\hline No & $\begin{array}{l}\text { Services Before } \\
\text { COVID-19 }\end{array}$ & $\begin{array}{l}\text { Services During } \\
\text { COVID-19 }\end{array}$ & Location \\
\hline 3 & $\begin{array}{l}\text { The service of making } \\
\text { lawsuit/ petition } \\
\text { and consultations is } \\
\text { provided during the } \\
\text { working hours of the } \\
\text { Religious Court }\end{array}$ & $\begin{array}{l}\text { Services for making } \\
\text { lawsuit/ petition in } \\
\text { Legal Aid Post are } \\
\text { carried out online, and } \\
\text { the consultation is not } \\
\text { limited to time (flexible) }\end{array}$ & $\begin{array}{l}\text { Legal Aid Post in } \\
\text { the Bandung and } \\
\text { Ngamprah Religious } \\
\text { Courts }\end{array}$ \\
\hline 4 & $\begin{array}{l}\text { There is no } \\
\text { postponement in } \\
\text { services except during } \\
\text { public holidays }\end{array}$ & $\begin{array}{l}\text { Postponement of making } \\
\text { lawsuit/ petition and } \\
\text { consultation services }\end{array}$ & $\begin{array}{l}\text { Legal Aid Posts in the } \\
\text { Depok and Sumedang } \\
\text { Religious Courts }\end{array}$ \\
\hline 5 & $\begin{array}{l}\text { There is no health } \\
\text { protocol such as } \\
\text { providing hand } \\
\text { sanitizers, the } \\
\text { requirement to keep } \\
\text { physical distance, and } \\
\text { wear masks }\end{array}$ & $\begin{array}{l}\text { Providing hand sanitizers, } \\
\text { requiring court visitors } \\
\text { to maintain physical } \\
\text { distance, and wear masks }\end{array}$ & $\begin{array}{l}\text { Legal Aid Posts in All } \\
\text { Religious Courts }\end{array}$ \\
\hline 6 & $\begin{array}{l}\text { There is no limitation } \\
\text { on the number of } \\
\text { people in a court } \\
\text { room }\end{array}$ & $\begin{array}{l}\text { There is a limitation of } \\
\text { the number of people } \\
\text { in a court room to only } \\
25-30 \% \text { of people out of } \\
\text { the usual number. }\end{array}$ & $\begin{array}{l}\text { Legal Aid Posts in All } \\
\text { Religious Courts }\end{array}$ \\
\hline 7 & $\begin{array}{l}\text { After the lawsuit is } \\
\text { made, the parties } \\
\text { go directly to the } \\
\text { registration counter, for } \\
\text { the case registration }\end{array}$ & $\begin{array}{l}\text { The parties are directed } \\
\text { to the E-Court corner } \\
\text { after receiving a lawsuit/ } \\
\text { petition from the Legal } \\
\text { Aid Post for the account } \\
\text { activation and online } \\
\text { registration }\end{array}$ & $\begin{array}{l}\text { Legal Aid Post in } \\
\text { Ngamprah Religious } \\
\text { Courts }\end{array}$ \\
\hline 8 & $\begin{array}{l}\text { Making a lawsuit } \\
\text { individually and take it } \\
\text { the to the registration } \\
\text { counter }\end{array}$ & $\begin{array}{l}\text { The lawsuit is made } \\
\text { online, After that, the } \\
\text { parties print the lawsuit/ } \\
\text { petition by themselves, } \\
\text { scan it and fill in the } \\
\text { E-Court registration form. } \\
\text { Then, the parties call the } \\
\text { number that has been } \\
\text { provided, send all the } \\
\text { required files and create } \\
\text { an active email to register } \\
\text { an E-Court account. }\end{array}$ & $\begin{array}{l}\text { Legal Aid Post in All } \\
\text { Religious Courts }\end{array}$ \\
\hline
\end{tabular}




\begin{tabular}{|clll|}
\hline No & \multicolumn{1}{c}{$\begin{array}{c}\text { Services Before } \\
\text { COVID-19 }\end{array}$} & \multicolumn{1}{c|}{$\begin{array}{c}\text { Services During } \\
\text { COVID-19 }\end{array}$} & \multicolumn{1}{c|}{ Location } \\
\hline 9 & $\begin{array}{l}\text { All officers are present } \\
\text { in their posts to } \\
\text { provide legal services } \\
\text { to the public }\end{array}$ & $\begin{array}{l}\text { There is a working } \\
\text { schedule in providing } \\
\text { legal services to the } \\
\text { public }\end{array}$ & $\begin{array}{l}\text { Legal Aid Posts in All } \\
\text { Religious Courts }\end{array}$ \\
\hline 10 & $\begin{array}{l}\text { There is no obligation } \\
\text { for the parties to register } \\
\text { using the E-Court }\end{array}$ & $\begin{array}{l}\text { The parties are required } \\
\text { to register using the } \\
\text { E-Court application }\end{array}$ & \\
\hline 11 & $\begin{array}{l}\text { The parties can choose } \\
\text { manual or E-Court } \\
\text { registration }\end{array}$ & $\begin{array}{l}\text { Manual registration is } \\
\text { limited to 15 cases, while } \\
\text { the E-Court registration } \\
\text { is not limited }\end{array}$ & $\begin{array}{l}\text { Legal Aid Post in } \\
\text { Soreang Religious } \\
\text { Courts }\end{array}$ \\
\hline
\end{tabular}

Source: Interviews with informants

From this table, it can be seen that the differences in the services provided by the Religious Courts before and during the COVID-19 pandemic. Of course, there are new methods maintained by Legal Aid Posts to deliver their services to the public. However, out of the eight Religious Courts, there were only 2 (two) Legal Aid Posts in the Religious Courts that provided online services during the LargeScale Social Restriction period, namely the Legal Aid Post of Bandung Religious Court and the Ngamprah Religious Court. Even though they did not use applications such as E-Court and E-Litigation, the have used WhatsApp platform. This shows that there are no service limits for the justice seekers under any circumstances. The challenge posed by the COVID 19 pandemic has forced the Religious Courts to make innovations, including innovations in the Legal Aid Post to optimize legal service delivery for justice seekers. Changes in the pattern of Legal Aid Post services in the Religious Courts follow the policies of each Religious Court, taking into account the situation and conditions of the region. Changes in service forms in Legal Aid Post can be categorized into several aspects, namely: officer, time, service delivery methods, enforcement of innovations/online legal aid services, and registration office. 


\section{Officer}

Legal Aid Post officers, in the time before COVID-19 pandemic, performed full legal services. However, during the COVID- 19 pandemic and Large-Scale Social Restrictions, a system has been developed to reduce the number of people in one room. They are also require to wear masks and other personal protective equipment during service.

\section{Time}

Before the COVID-19 pandemic, all Legal Aid Posts in the above mentioned Religious Courts carried out the same service hours, which was from 08.00 to 15.00 West Indonesian Time. This is different from the time during the pandemic. Several Legal Aid Posts have limited their services from 08.30 to $12.00 \mathrm{WIB}$, some even closed the services for reasons of safety of officers. Some have also offered flexible online services

\section{Service Delivery Methods}

During the COVID 19 pandemic, the Legal Aid Post have used different service delivery methods. Previously there were no restrictions, only prioritizing ethics and courtesy. During the COVID-19 pandemic, on the other hand, Legal Aid Posts, which continued to provide limited manual services, have implemented the health protocols by requiring visitors to maintain physical distancing; wear masks, and wash hands.

\section{Enforcement of Innovations/Online Legal Aid Post Services}

Several Legal Aid Posts during the COVID-19 pandemic made innovations by offering online services to reduce interactions and prevent virus transmission, especially in the COVID-19 red zones. Even though the service is provided using the WhatsApp platform, public enthusiasm to obtain legal information have remained although decreased in quantity.

\section{Registration Service}

Before COVID-19, after a lawsuit/ petition service was made, the parties were directed to copy the lawsuit/ petition. Then, they 
needed to visit the registration counter. Those who wanted to use the E-Court could go directly to the E-Court corner. Meanwhile, during the COVID-19 pandemic, several Religious Courts performed services manually, and some of the courts have used online registration via E-Court.

The development of online services during the COVID-19 pandemic and Large-Scale Social Restrictions is a manifestation of the goal of legal aid itself, namely increasing access to justice and providing excellent legal services to justice seekers (Cahyadi 2013: 35). This is very positive because people's knowledge about the legal process will have an impact on the increasing legal awareness and public protectionc. Therefore, the fulfillment of legal rights and access to the information of the law still can be obtained during the pandemic. Moreover, the use of technology is important to improve access to justice and the deal with mobilization restriction caused by the pandemic.

In terms of the implementation of the online Legal Aid Post service, the online services at Legal Aid Post of Bandung Religious Court only started in May 2020, whereas in the previous months-March and April-there was no online service available. There were only in the manuals and no online service offered at the Legal Aid Post of Bandung Religious Courts. Within that one month, there were twenty-two justice seekers who asked for consultation and preparation of legal documents, with the distribution as follow:

Table 3: The Parties' Need of Online Services in the Legal Aid Post of Bandung Religious Court

\begin{tabular}{|cc|}
\hline Needs & Total \\
\hline Document Preparation (Lawsuit/ petition) & 11 People \\
\hline Consultation & 11 People \\
\hline
\end{tabular}

Source: recapitulation of legal services number in Legal Aid Post of Bandung Religious Court

Meanwhile, at the Ngamprah Religious Court, the online Legal Aid Post service begins in April 2020 (starting from April 6 to April $21,2020)$ with a total of seventy-five people requested for the service. 
In May, the Ngamprah Religious Court has started to open registration manually for Legal Aid Post services, but on a limited basis. Thus, online services are no longer implemented.

Table 4: The Parties' Need of Online Services in Legal Aid Post of Ngamprah Religious Court

\begin{tabular}{|cc|}
\hline Needs & Total \\
\hline Document Preparation (Lawsuit/ petition) & 52 People \\
\hline Consultation & 23 People \\
\hline
\end{tabular}

Source: Legal Aid Post Performance Report in Ngamprah Religious Court

In the implementation of the service, there are similarities between the Legal Aid Post of Bandung and Ngamprah Religious Court, which is the use of WhatsApp platform. However, there are some differences in the form of service between the two Legal Aid Posts. In Bandung, the official website of the Court has provided information about direct contact numbers so that the people can directly obtain information and legal services from those contacts. Besides, such service has been integrated with the registration system via E-Court. In the Legal Aid Post of Ngamprah religious court, the parties still had to come to the Court. The information officer was given the number of the Legal Aid Post officer who would provide legal services. Registration must be carried out out by the party at the Court, even though it was via e-court.

Online services should be maximized without having the parties come to court by maximizing information through technology. In the end, it can reduce public mobility during the COVID-19 pandemic and reduce the risk of contact with the viruses. Besides, there are several advantages of the online system for Legal Aid Post service. Among them is time and cost efficiency because the parties do not need to come to the Court and they can access the service from any location. (Ika Atikah, 2018: 32). 


\section{Level of Public Access to the Religious Courts}

Access to the religious courts by litigants begins by visiting the Legal Aid Post before registering the case through the registration corner. Based on the data compiled from reports on Legal Aid Posts during March, April, and May 2020, especially during the LargeScale Social Restrictions period, the number of people who access the religious courts by submitting lawsuit/ petition has decreased, as described in table 5.

Table 5: Public Access to the Religious Courts during the COVID-19 Period

\begin{tabular}{|clccc|}
\hline \multirow{2}{*}{ No } & \multicolumn{1}{c}{ Religious Courts } & \multicolumn{3}{c|}{ Case Number } \\
\cline { 3 - 5 } & & March & April & May \\
\hline 1 & Bandung Religious Courts & 299 & 22 & 139 \\
\hline 2 & Soreang Religious Courts & 417 & 192 & 125 \\
\hline 3 & Ngamprah Religious Courts & 210 & 75 & 78 \\
\hline 4 & Karawang Religious Courts & 208 & 154 & 103 \\
\hline 5 & Depok Religious Courts & 190 & - & 0 \\
\hline 6 & Subang Religious Courts & 208 & 210 & 95 \\
\hline 7 & Sumedang Religious Courts & 163 & - & 0 \\
\hline 8 & Cimahi Religious Courts & 97 & 13 & 27 \\
\hline
\end{tabular}

Source: Lawsuit/ petition service report data in the legal aid post of each religious court.

Even though the data in table 5 above comes from the Legal Aid Post reports and not from the registration corners, it does not mean this data is invalid. This is based on the experience in the Religious Courts that applicants were represented by lawyers and did not use the Legal Aid Post services in each Court is only between 10\% to $15 \%$. This means that if the data above is increased by $10 \%-15 \%$ with the addition of justice seekers who use the services of lawyers and do not use legal aid post services, the rate continues to decrease.

Access to services in the Religious Courts during the COVID-19 pandemic is still diverse from one Religious Court to another. This depends on the policies of each Religious Court and the geographical 
conditions of the Religious Courts. Specifically, the Religious Courts that are located in "the red zone areas", such as Depok Religious Court, did not provide services at all. The Religious Courts of Sumedang, Bandung, and Ngamprah have responded to the situation by providing online services, including the legal aid services. In the Religious Courts of Soreang and Karawang, the Legal Aid Posts continue to provide face-to-face services with limited time, until 12.00 AM.

The decrease in the number of cases during the COVID-19 pandemic and Large-Scale Social Restrictions was due to the fact that, on the average, the Religious Courts imposed restrictions on services to justice seekers. Some of the Religious Courts decided to close the services temporary. The Religious Courts of Depok and Sumedang, for example, were closed for two months, from March and April. Some other courts, on the other hand, have provided services with limited working hours and the number of cases received.

Besides, with the rule that the number of people in one court room is limited to $25-30 \%$ of its capacity, the Legal Aid Post officers can deal with only limited number of people. This means they cannot serve a large number of justice seekers. Indeed, that situation should be tolerated and adapted by seekers of justice.

The online legal services carried out by Legal Aid Post in the Religious Courts are an effort to realize access to justice. The author argues that if the Religious Courts do not provide legal services including information and consultation, the public will find it difficult to deal with their legal problems, especially during the pandemic with social and economic pressures following it. This, in turn, will have consequences, one of which is that the justice seekers take inappropriate steps to find a solution to their problem.

From the data compiled by the authors, in two Religious Courts where the legal aid service is available online (Bandung and Ngamprah), divorce still dominates the cases during the COVID-19 pandemic and Large-Scale Social Restrictions. This shows that even people are forced to be at home, conflicts between husbands and wives can still happen and even can get worse with the intensity of the meeting. 
Table 6: Types of Online Service Cases in the Legal Aid Posts during the COVID-19 Pandemic and Large-Scale Social Restrictions

\begin{tabular}{|ccc|}
\hline Location & Case Types & Total \\
\hline & Divorce Lawsuit & 43 \\
\cline { 2 - 3 } $\begin{array}{c}\text { Legal Aid Post of } \\
\text { Ngamprah Religious } \\
\text { Courts }\end{array}$ & Talak Divorce & 6 \\
\cline { 2 - 3 } & Marriage Dispensation & 1 \\
\cline { 2 - 3 } & Marriage Isbat & 1 \\
\cline { 2 - 3 } & Guardianship & 1 \\
\cline { 2 - 3 } $\begin{array}{c}\text { Legal Aid Post of } \\
\text { Bandung Religious } \\
\text { Courts }\end{array}$ & Divorce Initiated by Wives & 23 \\
\cline { 2 - 3 } & Heirs Appointment & 2 \\
\hline & Marriage Dispensation & 11 \\
\hline
\end{tabular}

Source: the report and recapitulation of the Bandung Religious Court and the Legal Aid Post of Ngamprah Religious Court

The table illustrates the importance of legal services during the COVID-19 pandemic and Large-Scale Social Restrictions by the Religious Courts Legal Aid Post. Public access to online services by Legal Aid Posts can be carried out even though the users have been still very limited. This shows that solving problems emerged in public is impossible to be postponed. Additionally, the people need legal certainty for their problems.

Limiting access to legal services provided by Legal Aid Posts to the public During the COVID-19 pandemic and Large-Scale Social Restrictions has resulted in the uncertainty of the status of legal cases in society. The transition from the manual and conventional services to online methods needs to be accelerated. Social media can be used as a means to promote the online services provided by the Religious Courts during the pandemic. The lack of information among people regarding this, has made them ignorant and uninformed.

Legal aid is the constitutional right of every citizen, as stated in Article 1 paragraph (3) of the 1945 Constitution of the Republic 
of Indonesia. This means that under any circumstances, the system should be available to fulfill the needs and protect the human rights of citizens to access justice and equality before the law (Susanto, 2018: 179).

Online services, carried out by Legal Aid Post of Bandung and Ngamprah Religious Court, can be one example of innovation in the judiciary during the pandemic. This is because people can access judicial services from home, and in various situations. However, with some courts still require justice seekers to come to the Courts, as in Ngamprah Religious Court, the situation causes dilemma, not only for the justice seekers but also for the officers. With the Large-Scale Social Restrictions period, vehicle access was very limited, including public transport services.

During the pandemic, the cases of divorce filed by the wife continued to dominate, even though the numbers decreased. In this case, the author argues that during the pandemic, some wives in a problematic household do not want to have a prolonged domestic problems, and they fight for the legal certainty of their marital status and find solutions to their problem. In many cases in Indonesia, divorce initiated by women is often considered taboo. However, women will be able to file a divorce when they open their mind by considering that divorce is not a taboo and shameful thing, even divorce is a way out to resolve a prolonged conflict. Moreover, women need acknowledge that divorce is a right of a wife guaranteed by the law (Sururie, 2017: 23).

Leadership in the Religious Courts in crucial to realize the online services during the pandemic. There is a need for the leaders of the Religious Courts to make a strategic policy to change the mindset and habits of the officers, judicial apparatus, and the society. This is essential so that the online services provided can be maximized. The available facilities for the services will be useless if the apparatus still have conventional working mindset. It becomes sensible that the number of cases filed in the Religious Courts decreased. This is because people tended to delay their case registration waiting for the Courts to open the manual registration service. Some people might face a dilemma because they wanted to immediately to resolve their problems and get legal certainty. However, with the limited knowledge 
of online services at the Religious Courts and how to operate them, some people feel that it is better for them to wait.

Apart for that, the variety of cases received by the Legal Aid Posts at the Religious Courts during the pandemic has been also limited. Still, divorce dominates the cases. This is different with the normal period where the Legal Aid Post received more variety of cases with also varying level of difficulty. This can be an indicator that society is not yet familiar with the use of technology in the Religious Courts.

Table. 7. Comparison between Manual and Online Service Case Numbers since the Large-Scale Social Restrictions Period and the New Normal Period in Legal Aid Post of Bandung Religious Court

\begin{tabular}{|ccccccccccc|}
\hline \multicolumn{2}{|c}{ April } & \multicolumn{2}{c}{ May } & \multicolumn{2}{c}{ June } & \multicolumn{2}{c|}{ July } & \multicolumn{2}{c|}{ August } \\
\hline Manual & Online & Manual & Online & Manual & Online & Manual & Online & Manual & Online \\
\hline 21 & - & 117 & 22 & 633 & 8 & 606 & 22 & 541 & 6 \\
\hline
\end{tabular}

Source: Legal Aid Post Report of Bandung Religious Court.

The comparison data above shows that public interest in online services is still very minimal, in contrast to manuals. This decline is relatively obvious when it comes to the 'New Normal' period, the period when people can use public services with certain restriction and limitation, including strict health protocols.

The pandemic has restricted the mass mobility. Many activities are no longer upheld face-to-face but rather use virtual methods to prevent the spread of the virus. Therefore, the innovation in the Religious Courts is a must to provide virtual legal services.

Every court (General Courts, Religious Courts, State Administrative Courts, and Military Courts) has its service standards under their respective duties and functions (Mansyur, 2016). As explained above, this research shows that there are differences in the implementation of legal services provided by Legal Aid Posts in the Religious Courts during the pandemic. They have made adjustment to be able to provide access to justice for the people. Such adjustment depends significantly on the Courts' circumstances. According to Mansyur (2016), court 
service standards are adjusted to individual characteristics, such as geographical conditions and case characteristics.

Legal Aid Posts in the Religious Courts in West Java have attempted to innovate their public services to improve institutional performance and provide benefits to society (Anggadwita and Dhewanto, 2013: 27). The Legal Aid Posts in the Religious Court are required to maintain judicial processes effectively and efficiently (Sururie, 2012: 147). At the same time, the Religious Courts are also trying to provide innovation services by making various service adjustments during the COVID-19 pandemic. The Religious courts focus on digital and technological transformation to create and improve processes, according to a note from the Australian Public Service Commission (APSC) in 2016. This study reveals that almost all religious courts provide E-Court applications to help justice seekers obtain fast services. At least there are four applications carried out by the Supreme Court in the E-Court system, namely case recording (E-Filing), cash down payment (E-Payment) and notification, electronic court summons (E-Summons), and electronic litigation (E-Litigation).

The use of information technology helps Religious Courts improve efficiency in the case services. Empirically, investment in the field of technology can contribute to organizational performance (Rahmawati, 2008: 34). Therefore, information technology can help in speeding, consistency, accuracy, and reliability of organizations (Sutarman, 2009: 41). During the COVID-19 situation, Religious Courts and Legal Aid Post services can take advantages of information technology to still be able to provide legal access to the society.

Providing legal services in the Legal Aid Post during the COVID-19 pandemic and Large-Scale Social Restrictions is not an easy. There are several obstacles experienced by officers, especially those who provide online services. These obstacles are divided into two, facilities and culture.

According to the informant in this study, when the Legal Aid Post provides legal services online using the WhatsApp platform and telephone media, there are some limitations and obstacles. These include the unstable internet signals; the unavailability of internet services owned by justice seekers; and uneasy steps that should be 
carried out by justice seekers, such as printing the petition, scan it and submit it for online registration via E-Court. With this, the officers need to explain the process repeatedly to public.

The culture is a reflection of society and law enforcers' habits; ways of how to think and act (Praja, 2009: 65). During the pandemic, the difficulties faced by the justice seekers in accessing legal services has led to the decline in the number of cases received by the Legal Aid Posts. Besides, there has been no promotion of the online services in social media. People, then, still prefers the manual process rather than utilizing the information of technology innovation developed by the Legal Aid Posts of the Religious Courts. The public mindset still showed that the online services are difficult for them, despite of its significant roles during the pandemic.

Law develops following the changing times; and law is dynamic and not static. The COVID-19 period is a period of innovation for Legal Aid Post to provide services even with limitations. This is because legal aid brings social, economic, legal, and cultural resources closer to the society for the sake of creating justice, legal certainty, and benefits.

There must be a change in society's paradigm, especially during the COVID-19 pandemic to maintain society's health and the fulfilment of their legal rights. It is also important to be understood that the Legal Aid Post have duties to provide information, consultation, advice/ preparation of legal documents. However, there is also one more essential duty, which is to provide education to the society that they can still fight for their rights without having to come to the courts.

The innovations made by the Religious Court-based Legal Aid Posts during the COVID-19 pandemic is an answer to people's concerns about the solutions to their legal problems due to restrictions. Still, the law will not run automatically if people who have interests do not have an awareness, and are eager to take advantage of innovations that have been made (Sugono, Arianto, 2009: 89).

The period of full uncertainty in the COVID-19 era which had an impact on social, economic, and legal services was quickly responded by the religious court legal aid post, as a form of excellent service to the justice-seeking society, of course, such as the adage Justice 
delayed is justice denied, which means that delayed justice is a form of injustice (Djatmiko, 2019: 23).

The COVID-19 pandemic should not be a barrier in providing legal aid services to society. Under any circumstances, fiat justicia ruat coelum (Let justice be done though the heavens fall) is the basis of legal services during the COVID-19 pandemic. This can be done by various service models and innovations in each of the Religious Court Legal Aid Post. Adjustment of the service system in the Religious Court-based Legal Aid posts must be accompanied by supporting facilities. In this pandemic situation, the religious court must be able to maximize the available facilities that can help society obtain the information needed.

Society can take advantage of the independent lawsuit facility to make a lawsuit/ petition available on the website page of each Religious Court, so they do not have to always rely on a Legal Aid Post to make a lawsuit. The lack of socialization in society makes independent claims less desirable. Besides, the society itself is still unfamiliar with use of technology, such as computers and other devices. In this case, that the Legal Aid Posts still becomes the most favorable aid among the society that provide legal services, especially related to filing lawsuits/ petition.

A Legal Aid Post, in providing its services, does not only provide services to economically disadvantaged people but also to general people who have little knowledge about law and legal process (Rosita: 2019).

During the COVID-19 pandemic era, the Religious Courts can improve online services by using available technology, to reduce interaction between humans and minimize the spread of the virus. What needs to be underlined is that the Religious Court's Legal Aid Post are responsive in facing the COVID-19 pandemic situation and the Large-Scale Social Restrictions. This study provides evident of their responsiveness by revealing the variety service patterns provided by the Legal Aid Posts. Although public access has decreased, the spirit of providing legal assistance by the Legal Aid Posts should be appreciated. With that, people can still access justice and have their rights to obtain legal information.

The development of technology through the Legal Aid Post information system is a step to support the handling of various 
problems in the judicial sectors (Sarmuni: 2014). The courts help society to overcome obstacles to achieve a simple, fast, and low-cost trial. As a consequence, Legal Aid Posts can be considered as an institution that provides energy, thoughts, and legal work used in helping the litigants (Prabowo: 2017)

Even now, the provision of legal aid is an important issue in the field of national legal development. The legal aid is not simply about the access to legal assistance, but also about the concept of legal aid that is related to the fulfillment of economic and social rights for poor people (Fauzan: 2017). Legal aid programs are one of the ways to reach the equality of justice for society, which is important for legal development, particularly in Indonesia (Amran: 2016).

Based on the data obtained, in general, the existence of the Legal Aid Post has a positive impact on the performance of the Religious Courts. One of the things that is quite important in the provision of legal aid is that the system needs to pay attention to the administrative process based on applicable regulations. A theory from Anderson (2003) states that the success in the implementation of a certain activity must look at the administrative process and the impact of its implementation. Therefore, Legal Aid Posts in the Religious Courts as the party providing legal assistance must understand the process of how the duties and mechanisms run administratively and result in a positive impact. The Legal Aid Posts contribute to the Religious Courts by providing sufficient information supply to the individuals or groups, so they know the rights that they can fight for (Saepulah: 2013)

In the end, tools without enthusiasm are nothing. The enthusiasm from legal service officers is necessary to be considered, especially, legal aid posts in providing information and socialization to the public to take advantage of innovations and facilities provided by the Religious Courts in reducing interactions during the COVID-19 pandemic.

\section{Conclusion}

This study shows that the Legal Aid Post services provided by the Religious Courts during the Large-Scale Social Restrictions and COVID-19 Pandemic have been carried out in various forms, depending on the policies of each Religious Court, and the situation 
around the Religious Courts. These findings are in line with an adage in the world of law that "Let justice be done though the heavens fall" (fiat justitia ruat coelum). In other words, justice must be upheld (by providing legal aid services) even during the COVID-19 pandemic.

Meanwhile, the level of access to the Religious Courts during the COVID-19 pandemic has decreased. This finding is different from the previous studies stating that that access to justice for the Indonesian people is relatively good. The decline in the access to the Religious Courts has been due to the factor of adjusting the procedures carried out by the Religious Courts. At the same time, justice seekers still find it difficult to deal with the technological innovation used in the Legal Aid Posts in the Religious Courts, The Religious Courts continue to develop innovations by adopting advanced information technology to enable the people to get access to justice during the difficult time of COVID-19 pandemic.

\section{References}

Abdurrahman, Humaedi. (2020). (Advokat Pengadilan Agama Sumedang). Interview, Bandung, 30 April.

Amran, A. (2016). Eksistensi Pos Bantuan Hukum (POSBAKUM) di Pengadilan Agama Sungguminasa. (Doctoral dissertation, Universitas Islam Negeri Alauddin Makassar).

Anderson, (2003). Prinsip-Prinsip Perumusan Kebijakan Negara. Jakarta: Bumi Aksara, Cet. ke-12.

Anggadwita, G. (2013). "Service innovation in public sector: a case study on PT. Kereta Api Indonesia”. Journal of Social and Development Sciences, 4(7), 308-315.

Anggraeni, R. D. (2020). "Wabah Pandemi COVID-19, Urgensi Pelaksanaan Sidang Secara Elektronik". ADALAH, 4(1), 7-12.

Anwar, R. (2020). Bagaimana pengadilan menghadapi pandemic COVID-19? Diskusi virtual Ditjen Badilag dan Family Court of Asutralia. Retrieved from https://badilag.mahkamahagung.go.id/seputar-ditjen-badilag/seputarditjen-badilag/bagaimana-pengadilan-menghadapi-pandemi-covid19-diskusivirtual-ditjen-badilag-dan-family-court-of-australia, accessed May 2020

Arif, Asep Hamdan. 2020. (Advokat Agama Ngamprah). Interview, Bandung, 4 Mei.

Atikah, Ika. (2018). "Implementasi E-Court dan Dampaknya Terhadap Advokat Dalam Proses Penyelesaian Perkara di Indonesia”. Proceding-Open Siciety Conference.

Australian Public Service Commission (2016). State of the Service Report 
2015-2016. Retrieved from http://www.apsc.gov.au/_data/assets/pdf_ file/0008/89225/SoSR-2015-16.pdf, Accessed March 2020.

Cahyadi, Thalis Noor. (2013). "Efektifitas Pos Bantuan Hukum di Pengadilan (Studi Pada Posbakum Pengadilan Agama Sleman Tahun 2011-2012)”. Rechtvindings 2(1). 17-30.

Djatmiko, H. (2019). Implementasi Peradilan Elektronik (e-Court) Pasca Diundangkannya PERMA Nomor 3 Tahun 2018 Tentang Administrasi Perkara di Pengadilan secara Elektronik. Legalita, 1(1), 22-32.

Fauzan, F. (2018). Penerapan Pemberian Bantuan Hukum Bagi Masyarakat Miskin Melalui Posbakum Di Pengadilan Agama Kota Bengkulu. Mizani: Wacana Hukum, Ekonomi Dan Keagamaan, 4(2), 125-134.

Hamdadin, Zeni. 2020 (Advokat Pengadilan Agama Soreang). Interview. Bandung, 3 Mei.

Juaningsih, Imas Novita (2020). "Penerapan Sanksi Pidana bagi Penimbun Masker di Indonesia Selama Masa Pandemi COVID-19” dalam 'Adalah: Buletin Hukum dan Keadilan. 4 (1).

Mansyur, R. (2016). "Information Transparency in the Court in Order to Implement Certain Integrity Implementation and Legal". J. Law Justice, 4(3).

Matos, Jose Igreja, (2020), “Acces to Justice in Time of Judicial Lockdown” dalam http://www.unodc.org/dohadeclaration/en/news/2020/03/acces-to-justice-intimes-of-judicial-lockdown.html.

Mutakin, Dede. 2020. (Panitera Pengadilan Agama Soreang). Interview, Bandung, 3 Mei.

Prabowo, A. (2017). Peran Pos Bantuan Hukum (Posbakum) di Pengadilan Agama Bengkulu Kelas IA Berdasarkan Peraturan Mahkamah Agung Republik Indonesia Nomor 1 Tahun 2014. Qiyas: Jurnal Hukum Islam dan Peradilan, 2(2).

Praja, J. S. (2009). Teori-Teori Hukum Suatu Telaah Perbandingan Dengan Pendekatan Filsafat. Bandung: Pasca UIN Sunan Sunan Gunung Djati.

Rahmawati, Diana, (2008, April). Analisis Faktor-Faktor Yang Berpengaruh Terhadap Pemanfaatan Teknologi Informasi, Jurnal Ekonomi \& Pendidikan, 5 (1).

Risnawati. 2020. (Petugas Posbakum Pengadilan Agama Cimahi). Interview, Bandung, 30 April.

Rosita, R. (2019). Eksistensi Pos Bantuan Hukum dalam Memberikan Bantuan Hukum di Pengadilan Agama Kelas IB Watampone. Ekspose: Jurnal Penelitian Hukum dan Pendidikan, 16(1).

Saefudin, Acep. (2020). (Ketua Pengadilan Agama Bandung). Wawanccara Pribadi, Bandung, 4 Mei)

Saepullah, U. (2013). Peranan POSBAKUM di Pengadilan Agama. Adliya, Jurnal Hukum dan Kemanusiaan. 
Selviana. 2020. (Petugas E-Court Pengadilan Agama Ngamprah). Interview, Bandung, 30 April.

Sodik, Aziz Ahmad. 2020. (Advokat Pengadilan Agama Depok). Interview, Bandung, 1 Mei.

Sururie, Ramdani Wahyu. (2018). Darurat Perceraian dalam Keluarga Muslim Indonesia. LP2M: Universitas Islam Negeri Sunan Gunung Djati Bandung.

Sururie, Ramdani Wahyu. (2012). Implementasi Mediasi dalam Sistem Peradilan Agama. Ijtihad: Jurnal Wacana Hukum Islam dan Kemanusiaan, 12(2).

Susanto, Y. A., Kania, D., \& Burhanuddin, H. (2018). Bantuan Hukum Bagi Masyarakat Miskin di Pengadilan Agama Cimahi Tahun 2016. Jurnal AsySyariah, 20(2).

Sutarman. (2009). Pengantar Teknologi Informasi. Jakarta: Bumi Aksara.

Zaenal, Dadang. 2020. (Panitera Pengadilan Agama Subang). Interview, Bandung, 1 Mei.

Ramdani Wahyu Sururie ${ }^{1} \&$ Yoghi Arief Susanto ${ }^{2}$

${ }^{1,2}$ Universitas Islam Negeri Sunan Gunung Djati Bandung, Indonesia

E-mail: ${ }^{1}$ ramdaniwahyusururie@uinsgd.ac.id, ${ }^{2}$ yoghiariefsusanto@gmail.com 